\author{
Jakub Bartak \\ Łukasz Jabłoński
}

\title{
Znaczenie nierówności dochodowych dla inwestycji w kapitał ludzki w latach 1970-2012*
}

\section{Streszczenie}

Celem artykułu jest identyfikacja wpływu nierówności dochodowych na inwestycje w kapitał ludzki w wybranych krajach w latach 1970-2012. Dokonano tego przez oszacowanie funkcji regresji ilościowych oraz jakościowych inwestycji w kapitał ludzki. Oparcie analizy na danych panelowych umożliwiło kontrolowanie efektów indywidualnych, czasowych i losowych, co stanowi wkład do rozważań o ilościowych związkach między badanymi zmiennymi. Wyniki oszacowań wskazują na istnienie negatywnej zależności między nierównościami dochodowymi a ilościowymi inwestycjami w kapitał ludzki. Wykazano także, że ta negatywna zależność odporna jest na specyfikację modelową. Uzyskane wyniki nie pozwalają natomiast na wyciągnięcie jednoznacznych wniosków dotyczących zależności między nierównościami dochodowymi a inwestycjami w kapitał ludzki w wymiarze jakościowym.

Jakub Bartak, Uniwersytet Rzeszowski, Wydział Ekonomii, Katedra Mikroekonomii, ul. Ćwiklińskiej 2, 35-601 Rzeszów, e-mail: jbartak@ur.edu.pl

Łukasz Jabłoński, Uniwersytet Ekonomiczny w Krakowie, Wydział Towaroznawstwa, Katedra Ekonomii Stosowanej, ul. Rakowicka 27, 31-510 Kraków, e-mail: lukaszj@uek.krakow.pl

* Artykuł powstał w wyniku realizacji projektów badawczych autorów: projektu zrealizowanego ze środków przeznaczonych na badania statutowe Katedry Mikroekonomii Uniwersytetu Rzeszowskiego oraz projektu finansowanego ze środków przyznanych Wydziałowi Towaroznawstwa Uniwersytetu Ekonomicznego w Krakowie w ramach dotacji na utrzymanie potencjału badawczego. 
Słowa kluczowe: kapitał ludzki, nierówności dochodowe, endogeniczna teoria wzrostu gospodarczego, efekty indywidualne.

Klasyfikacja JEL: E24, I24, J24.

\section{Wprowadzenie}

Nierówności w podziale dochodów wewnątrz krajów i kapitał ludzki tworzą popularny obszar badań w ekonomii. Prace nad zagadnieniami nierówności dochodów w połowie ubiegłego wieku zapoczątkował S. Kuznets [1955]. W latach 70. i 80. XX w. zainteresowanie nierównościami podziału dochodów indywidualnych było marginalne, ale już w latach 90 . XX w. za sprawą A.B. Atkinsona [1997] na gruncie badań ekonomicznych stopniowo wzrastało'. Szczególne zainteresowanie nierównościami przypada na początek XXI w., gdyż jak podkreśla wielu ekonomistów (m.in. [Stiglitz 2010, Stockhammer 2015]), osiągnęły one na tyle wysoki poziom, że zagrożona została stabilność realnych procesów ekonomicznych.

Kapitał ludzki, rozumiany jako nagromadzone w wyniku działalności inwestycyjnej kwalifikacje, umiejętności i zdrowie ludzi umożliwiające wykonywanie im pracy, stał się tematem rozważań T.W. Schultza [1961], J. Mincera [1958, 1962], E. Denisona [1962], a zwłaszcza G.S. Beckera [1962, 1964] (zob. [Domański 1993]). Jednak największy wpływ na spopularyzowanie badań nad kapitałem ludzkim miał rozwój endogenicznej teorii wzrostu gospodarczego, w której akumulacja tego czynnika wytwórczego ma kluczowe znaczenie dla wyjaśniania wzrostu produktu w długim okresie [Lucas 1988, Romer 1986].

Badania wpływu nierówności dochodowych na kapitał ludzki są prowadzone w kontekście uwarunkowań akumulacji kapitału ludzkiego jako siły sprawczej wzrostu gospodarczego. Wiele kontrowersji wzbudza z jednej strony wyodrębnienie teoretycznych kanałów wpływu nierówności na kapitał ludzki, zaś z drugiej - osiągnięcie konsensusu wśród ekonomistów w zakresie tego, który z tych kanałów w większym stopniu wyjaśnia tę zależność [Galor 2012]. Niemniej jednak można wskazać kilka hipotetycznych kanałów, za pośrednictwem których zróżnicowania dochodowe wewnątrz krajów negatywnie wpływają na akumulację kapitału ludzkiego (zob. np. [Bartak 2015]), tj. m.in.:

${ }^{1}$ Rozpoczęte w latach 50. XX w. rozważania nad związkami między wzrostem gospodarczym i nierównościami nie przyniosły rozwiązania satysfakcjonującego szerszego gremium ekonomistów. Sprowadzały się one bowiem do podejmowanych prób rozwiązania dylematu: równość (egalitaryzm) czy (wzrost) efektywność. Wobec tak sformułowanego problemu ekonomiści w naturalny sposób bagatelizowali problem nierówności na rzecz gloryfikacji wzrostu gospodarczego (zob. [Putterman, Romer i Silvestre 1998]). 
- bodźce inwestycyjne [Bell i Freeman 2001, Galor i Tsiddon 1997, Welch 1999],

- oszczędności [Bertrand i Morse 2015, Frank, Levine i Dijk 2014], szczególnie w warunkach niedoskonałości rynku kredytowego [Galor i Zeira 1993, Galor 2011, Foellmi i Zweimüller 2003],

- publiczne inwestycje edukacyjne [Rajan i Zingales 2006, Anderson, Mellor i Milyo 2008],

- procesy demograficzne [Galor i Weil 2000, Dahan i Tsiddson 1998, Becker, Murphy i Tamura 1990],

- zdrowie [Lynch i in. 2004, Leigh, Jencks i Smeeding 2009].

Również badania empiryczne potwierdzają dość jednoznaczne wnioski dotyczące wpływu zróżnicowań dochodowych na akumulację kapitału ludzkiego. Większość autorów zgadza się co do tego, że większe zróżnicowania dochodowe w gospodarce negatywnie wpływają na kapitał ludzki [Perotti 1996], zwłaszcza na wyższym poziomie rozwoju gospodarki [Battisti, Fioroni i Lavezzi 2014, Papageorgiou i Razak 2009].

Warto podkreślić, że w międzynarodowych badaniach porównawczych można zauważyć zmianę podejścia do empirycznej weryfikacji kierunku tych zależności. Dotyczy to zwłaszcza uwzględniania efektów indywidualnych, które, jak się wydaje, są odpowiedzialne za niejednoznaczności wyników badań empirycznych nad wpływem zmian zróżnicowań dochodowych na wzrost gospodarczy.

Empiryczne badania nad wpływem nierówności dochodowych na akumulację kapitału ludzkiego zainicjował R. Perotti [1996], który na podstawie przekrojowych danych z lat 60. i 70. XX w., stosując metodę najmniejszych kwadratów, wykazał, że rosnący odsetek klasy średniej dodatnio wpływa na skolaryzację średniego poziomu kształcenia. Jako zmienne kontrolne użył on poziom rozwoju gospodarczego kraju (PKB per capita), zasób kapitału ludzkiego oraz zmienną dychotomiczną pozwalającą wyodrębnić kraje biedne. Wyniki tych badań ilustrują negatywny wpływ rosnących nierówności dochodowych nie tylko na akumulację kapitału ludzkiego, lecz pośrednio także na wzrost gospodarczy.

Do zbliżonych wniosków dochodzą także M. Battisti, T. Fioroni i A.M. Lavezzi [2014], którzy w analizie wykorzystującej potrójną metodę najmniejszych kwadratów, akumulację kapitału ludzkiego ujmują jako jedno z równań opisujących wzrost gospodarczy. Jako zmienną objaśniającą w równaniu kapitału ludzkiego użyli oni zasób tego czynnika produkcji w poprzednim okresie. W konsekwencji autorzy [Battisti, Fioroni i Lavezzi 2014] sugerują, że nierówności dochodowe brutto ujemnie wpływają na kapitał ludzki w krajach rozwiniętych, a w krajach biednych wpływ ten jest nieistotny statystycznie.

Warto podkreślić, że R. Perotti [1996], a także M. Battisti, T. Fioroni i A.M. Lavezzi [2014] w analizie empirycznej nie uwzględnili efektów indy- 
widualnych dla krajów objętych badaniem. Tymczasem ustalenia empiryczne (zob. [Ehrhart 2009]) wskazują, że kontrowersje związane z szacunkami wpływu nierówności dochodowych na wzrost gospodarczy wiążą się właśnie z kontrolowaniem efektów indywidualnych. W szczególności z estymacji ujmujących te efekty wynika często dodatni wpływ nierówności na wzrost gospodarczy [Forbes 2000], podczas gdy z szacunków opartych na danych przestrzennych bądź analizie naiwnej danych panelowych - ujemny wpływ zróżnicowań dochodowych na wzrost gospodarczy. Interesującym przedmiotem badań jest zatem zweryfikowanie, czy postać równania, które kwestionuje wyniki badań wzrostu gospodarczego opartych na danych przekrojowych, ma podobne znaczenie w przypadku równania kapitału ludzkiego.

Celem badania jest zidentyfikowanie zależności między nierównościami dochodowymi a inwestycjami w kapitał ludzki w 105 krajach w latach 1970-2012 po pierwsze z uwzględnieniem efektów indywidualnych, po drugie $\mathrm{z}$ ich pominięciem.

\section{Metoda badawcza}

W badaniu podjęto próbę określenia znaczenia zmian nierówności dochodowych dla akumulacji, a zwłaszcza inwestycji w kapitał ludzki. Badanie oparto na równaniu regresji inwestycji w kapitał ludzki, dzięki czemu możliwe było uchwycenie krótkookresowego i średniookresowego wpływu nierówności dochodowych na kapitał ludzki w badanych krajach. Jednocześnie zwracając uwagę na inwestycje, a więc nakłady na kapitał ludzki, można było pominąć kwestie deprecjacji kapitału ludzkiego, a więc związane z naturalnym procesem starzenia oraz opuszczania rynku pracy przez starzejące się grupy pracowników o różnym poziomie nagromadzonego kapitału ludzkiego [Domański 1993].

Warto podkreślić, że inwestycje w kapitał ludzki wynikają z wielu kompleksowych i wzajemnie wzmacniających się czynników i okoliczności. W związku z tym w badanym równaniu regresji wśród zmiennych objaśniających ujęto nie tylko nierówności dochodowe, lecz również inne potencjalne siły sprawcze inwestycji w kapitał ludzki związane z nagromadzonym w poprzednich okresach zasobem tego czynnika produkcji, urbanizacją oraz poziomem rozwoju gospodarczego.

Wybór innych niż nierówności dochodowe zmiennych objaśniających wymaga krótkiego komentarza. Ujęcie kapitału ludzkiego nagromadzonego w poprzednich okresach jako zmiennej objaśniającej strumień napływu tego czynnika produkcji wynika z rozstrzygnięć teoretycznych sugerujących, że kapitał ludzki niesie ze sobą liczne efekty zewnętrzne ułatwiające jego dalszą akumulację. Wielu autorów podkreśla znaczenie środowiska rodzinnego dla rozwoju kapitału ludzkiego kolej- 
nego pokolenia osób (m.in. [Tamura 2004, Glomm i Ravikumar 1992, Benabou 1996a, b, Fernandez i Rogerson 1998, 2003, de la Croix i Doepke 2003]), a także bodźców do dalszych inwestycji w kapitał ludzki wynikających z wdrażanych nowych technologii i występującym dzięki temu popytem na wykwalifikowaną siłę roboczą (m.in. [Azariadis i Drazen 1990]). W związku z tym w większości modeli wzrostu gospodarczego akumulacja kapitału ludzkiego jest funkcją zasobu tego czynnika wytwórczego nagromadzonego w poprzednich okresach (m.in. [Lucas 1988, Romer 1990, Benabou 1996a, Fernandez i Rogerson 1998]).

$\mathrm{Z}$ teoretycznych badań nad gospodarką dualną wynika, że sektor tradycyjny (rolniczy) charakteryzuje się mniej korzystnymi warunkami dla akumulacji kapitału ludzkiego niż sektor nowoczesny (m.in. [Azariadis 1996, Masson 2001]). Może to wynikać z mniej korzystnego dostępu do edukacji na terenach wiejskich niż w miastach, zwłaszcza w krajach o niskiej gęstości zaludnienia i słabo rozwiniętej infrastrukturze transportowej. Zatem w diagnozie sił sprawczych inwestycji w kapitał ludzki znaczenie zyskuje również stopień urbanizacji jako ważna determinanta inwestycji w kapitał ludzki.

Z kolei zastosowanie rozwoju gospodarczego jako zmiennej w zakresie inwestycji w kapitał ludzki wynika z teoretycznych i empirycznych argumentów sugerujących, że poziom rozwoju gospodarki determinuje zapotrzebowanie na kapitał ludzki (zob. [Jabłoński 2011, s. 94-95]). W szczególności z modeli eksponujących efekty progowe (threshold externalities) [Azariadis i Drazen 1990] oraz efekty zewnętrzne związane z nauką przez doświadczenie (learning-by-doing) [Lucas 1988] wynika, że poziom rozwoju gospodarczego można traktować jako czynnik kapitału ludzkiego. P. Romer [1986, 1990] i R.F.J. Lucas [1988] wyjaśnili, że akumulacja kapitału ludzkiego i wiedzy naukowo-technicznej jest źródłem długookresowego wzrostu gospodarczego. W celu utrzymania dodatniego tempa wzrostu produktu konieczne jest inwestowanie w kapitał ludzki i wiedzę naukowo-techniczną. W związku z tym długookresowy wzrost gospodarczy i akumulacja kapitału ludzkiego są wzajemnie napędzającymi się procesami, co oznacza, że bez kapitału ludzkiego nie ma długookresowego wzrostu gospodarczego oraz bez długookresowego wzrostu gospodarczego nie ma akumulacji kapitału ludzkiego.

Jednak uwzględnienie wśród zmiennych objaśniających poziomu rozwoju gospodarczego wespół ze zmienną ilustrującą nagromadzony w poprzednich okresach kapitał ludzki może stwarzać pewne zagrożenia dla jakości uzyskanych wyników. Wynika to z silnego skorelowania rozwoju gospodarczego i nagromadzonego zasobu kapitału ludzkiego w gospodarce. Z obserwacji empirycznych, a także rozstrzygnięć teoretycznych wynika, że na wyższym poziomie rozwoju gospodarczego zasób kapitału ludzkiego jest większy [Mankiw, Romer i Weil 1992, Klenow i Rodríguez-Clare 1997]. Jednocześnie w modelach wzrostu endogenicznego poziom rozwoju gospodarczego jest często utożsamiany z wielkością zasobu 
kapitału ludzkiego (m.in. [Azariadis i Drazen 1990, Benabou 1996a, b]). Z tego względu istnieją obawy, że ujęcie wśród zmiennych objaśniających jednocześnie rozwoju gospodarczego oraz nagromadzonego zasobu kapitału ludzkiego może być niekorzystne dla jakości uzyskanych wyników. W celu uniknięcia problemu oszacowano także parametry równań regresji inwestycji w kapitał ludzki bez rozwoju gospodarczego jako zmiennej objaśniającej.

W związku z tym oszacowano parametry następujących równań:

$$
\begin{gathered}
\text { Hinv }_{i, t}=\beta_{0}+\beta_{1} \text { ineq }_{i, t-1}+\beta_{2} H_{i, t-1}+\beta_{3} \text { urban }_{i, t-1}+\beta_{4} \operatorname{dev}_{i, t-1}+\eta_{i, t}, \\
\text { Hinv }_{i, t}=\beta_{0}+\beta_{1} \text { ineq }_{i, t-1}+\beta_{2} H_{i, t-1}+\beta_{3} \text { urban }_{i, t-1}+\eta_{i, t},
\end{gathered}
$$

gdzie:

$H_{i n v_{i, t}}$ - inwestycje w kapitał ludzki w $i$-tym kraju i $t$-tym okresie,

ineq $_{i, t-1}$ - nierówności dochodowe $\mathrm{w} i$-tym kraju i okresie poprzednim $(t-1)$,

$H_{i, t-1}$ - zasób kapitału ludzkiego w $i$-tym kraju i okresie poprzednim $(t-1)$,

urban $_{i, t-1}$ - urbanizacja w $i$-tym kraju w okresie poprzednim $(t-1)$,

$d e v_{i, t-1}$ - poziom rozwoju gospodarczego $i$-tego kraju w okresie poprzednim $(t-1)$,

$\beta_{0}, \ldots, \beta_{4}$ - parametry regresji,

$\eta_{i, t}$ - reszta.

Parametry równań regresji o postaciach (1) i (2) oszacowano klasyczną metodą najmniejszych kwadratów (MNK) z ustalonymi efektami stałymi (fixed effects), $\mathrm{z}$ efektami losowymi (random effects) oraz z ustalonymi efektami czasowymi (estymator pooled ze zmiennymi dychotomicznymi obrazującymi rok analizy), (por. [Baltagi 2013, s. 14-25]). Dla oszacowanych parametrów równań regresji wykonano testy diagnostyczne weryfikujące istotność indywidualnych efektów stałych, efektów losowych, test Hausmana oraz test na obecność heteroskedastyczności reszt estymowanych równań (por. [Baltagi 2013, s. 68-96]). Ze względu na wykazaną heteroskedastyczność interpretację istotności statystycznej poszczególnych oszacowań oparto na odpornych błędach standardowych.

\section{Zmienne makroekonomiczne i źródła ich danych liczbowych}

Badanie przeprowadzono na danych czasowo-przekrojowych, składających się z 6 wskaźników odzwierciedlających inwestycje w kapitał ludzki i istniejący zasób tego czynnika produkcji w badanych krajach, a także zróżnicowania dochodowe wewnątrz krajów, urbanizację i poziom rozwoju gospodarczego.

Inwestycje w kapitał ludzki odzwierciedlono dwoma wskaźnikami o charakterze ilościowym i jakościowym. Jako miernik ilościowy wykorzystano wskaźnik skolaryzacji na poziomie średnim brutto (Enr_sec), którego wartości liczbowe 
zaczerpnięto z bazy danych UNESCO (http://data.uis.unesco.org/?queryid=142\#, data dostępu: 1.06.2016). Informuje on o odsetku osób uczących się w szkołach średnich wśród populacji w wieku charakterystycznym dla średniego poziomu kształcenia. Jest on często wykorzystywany w badaniach empirycznych ze względu na względnie dużą dostępność danych liczbowych i porównywalność międzynarodową. Należy jednak podkreślić, że zasadnicza słabość tego wskaźnika wiąże się z tym, że nie uwzględnia on jakości zdobywanej edukacji w różnych krajach i okresach. Niemniej jednak można go traktować jako miernik inkluzyjności systemu edukacyjnego, zaś niskie jego wartości należy interpretować jako przejaw wykluczenia szerokich grup społecznych ze współczesnych procesów gospodarki opartej na wiedzy i innowacyjności.

W celu uwzględnienia jakości inwestycji w kapitał ludzki w badaniu użyto wskaźnika ilustrującego przeciętne wyniki testów kompetencji i umiejętności (Edu_achiev) zawarte w bazie danych Edukacyjnych Osiągnięć Globalnych (Education Global Achievement) udostępnianej przez Bank Światowy (http://datatopics.worldbank.org/Education/wDataQuery/QAchievement.aspx, data dostępu: 1.06.2016). Baza ta, stworzona na podstawie międzynarodowych testów kompetencji i umiejętności PISA, TIMSS ${ }^{2}$ oraz szeregu inicjatyw o mniejszym zasięgu, zawiera zestaw porównywalnych danych obejmujących również kraje rozwijające się, które nie uczestniczyły w najbardziej popularnych testach osiągnięć edukacyjnych [Angrist, Patrinos i Schlotter 2013].

Poziom zasobu kapitału ludzkiego nagromadzonego w poprzednich okresach $(H)$ odzwierciedlono przeciętną liczbą lat nauki, których wartości liczbowe pozyskano z bazy, którą utworzyli R.J. Barro i J.W. Lee [2013], z kolei stopień urbanizacji - odsetkiem populacji żyjącej w mieście (urban), zaś poziom rozwoju gospodarczego - PKB per capita (wyrażone w dolarach amerykańskich w cenach stałych z 2005 r.). Wartości liczbowe wskaźników urbanizacji i rozwoju gospodarczego pozyskano z bazy danych Banku Światowego (http://data.worldbank.org, data dostępu: 8.02.2016). Jako miernik nierówności dochodowych wewnątrz krajów w badaniu użyto wartości liczbowych współczynnika Giniego dla dochodów rozporządzalnych netto zaczerpniętych z bazy danych SWIID (Standardized World Income Inequality Database) stworzonej przez F. Solta $[2014]^{3}$.

Wartości liczbowe wykorzystane w badaniu zmiennych objaśniających pochodzą z lat 1963-2008, wartości współczynnika skolaryzacji (Enr_sec)

2 Testy PISA badają umiejętność czytania ze zrozumieniem oraz rozwiązywania zadań matematycznych, przyrodniczych wśród młodzieży w wieku 15-16 lat, natomiast testy TIMSS dotyczą tylko nauk przyrodniczych i matematyki.

${ }^{3}$ Dane SWIID powstały na podstawie procedury wielokrotnego przypisywania. W niniejszej pracy wykorzystano uśrednione wskaźniki uzyskane tą procedurą. 
z lat 1970-2012, a przeciętne wyniki testów edukacyjnych (Edu_achiev) z lat 1970-2010. Dane podzielono na 5-letnie okresy i wszelkich estymacji dokonano na podstawie średnich arytmetycznych $\mathrm{w}$ tych okresach. Zgodnie z przyjętą metodyką badania (pkt 2) wszystkie zmienne objaśniające opóźnione są o jeden okres.

\section{Wyniki badań empirycznych}

W tabelach 1 i 2 zawarto wyniki oszacowań parametrów równań (1) i (2) wraz z oceną ich statystycznej istotności, a także informację dotyczącą liczebności próby, efektów czasowych oraz wartości współczynników determinacji. Tabela 1 zawiera wyniki estymacji tych równań, gdzie zmienną objaśnianą były inwestycje w kapitał ludzki w ujęciu ilościowym, a więc wartości wskaźnika skolaryzacji średniego poziomu kształcenia (Enr_sec), zaś w tabeli 2 - inwestycje w ten czynnik wytwórczy w ujęciu jakościowym, zilustrowane wynikami testów kompetencji i umiejętności (Edu_achiev).

$\mathrm{Z}$ tabel 1 i 2 wynika, że parametry oszacowanych równań, charakteryzujących się zadowalającą istotnością statystyczną przyjęły znaki wartości, tj. ujemne bądź dodatnie, zgodne z wnioskami teoretycznymi. W szczególności nasuwają się następujące wnioski:

- nierówności dochodowe negatywnie wpływają na akumulację kapitału ludzkiego,

- zastane zasoby kapitału ludzkiego wspierają jego dalszą akumulację,

- poziom rozwoju gospodarczego pozytywnie determinuje akumulację kapitału ludzkiego,

- koncentracja ludności w miastach ułatwia akumulację kapitału ludzkiego.

Z porównania wartości testu Hausmana (tabela 3) obliczonych dla badanych równań wynika, że większą wiarygodnością statystyczną charakteryzują się równania $\mathrm{z}$ indywidualnymi efektami stałymi (FE) w stosunku do tych $\mathrm{z}$ efektami losowymi (RE). We wszystkich wariantach badanych równań, również w tych, które ujmują stałe efekty indywidualne (FE) nierówności dochodowe, mierzone współczynnikiem Giniego dla dochodów rozporządzalnych netto, negatywnie oddziałują na skolaryzację średniego poziomu kształcenia. Co ciekawe, w odróżnieniu od modeli wzrostu gospodarczego ujęcie efektów stałych nie zmienia oceny wpływu nierówności dochodowych na kształtowanie się badanego procesu. W tym sensie otrzymane wyniki dostarczają interesujących informacji dla empirycznych badań wzrostu gospodarczego. Podają bowiem w wątpliwość zasadność łącznego uwzględniania zmiennej kapitału ludzkiego i nierówności dochodowych w równaniach wzrostu, gdyż zmienna kapitału ludzkiego przejmować może efekty nierówności dla wzrostu. Jednocześnie dużym wyzwaniem pozostaje 


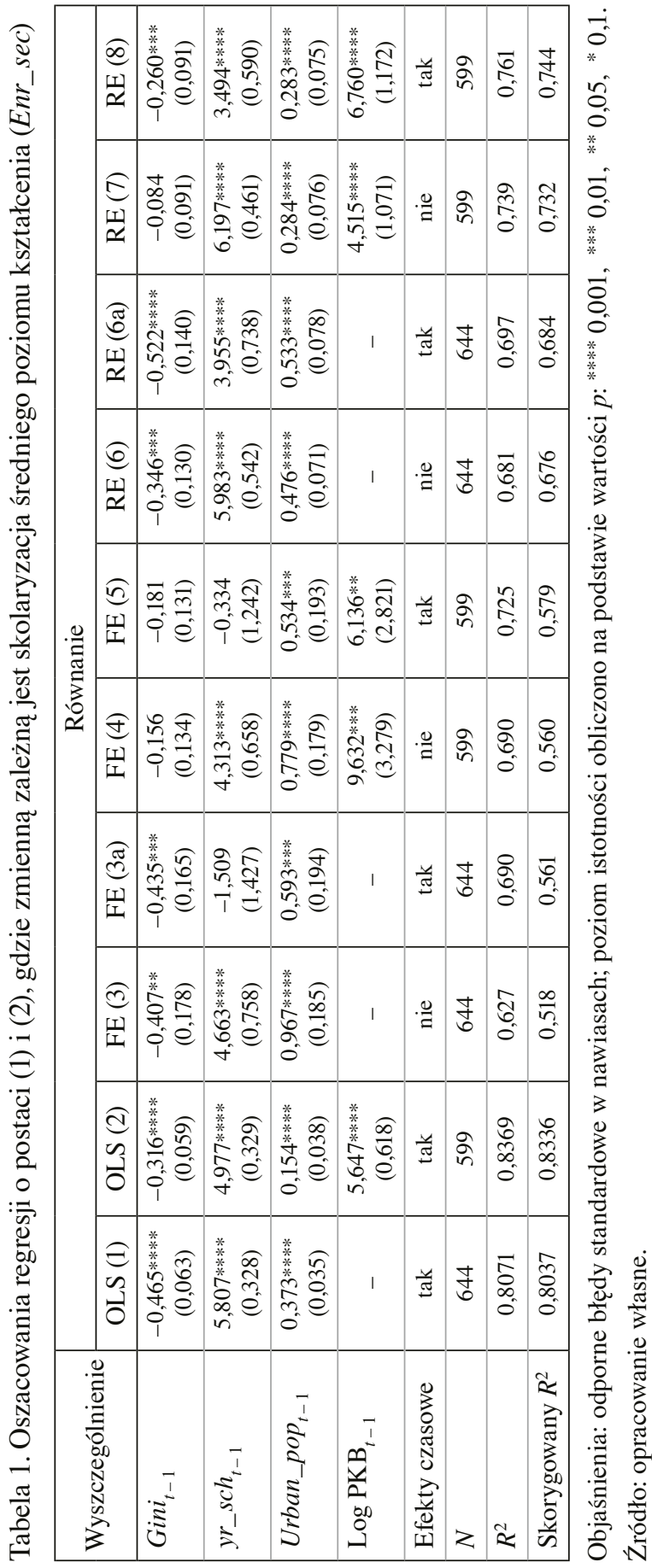


zweryfikowanie, które z kanałów oddziaływania nierówności na wzrost gospodarczy odpowiadają za pozytywny efekt dysproporcji dochodowych dla wzrostu wykazanych w badaniach empirycznych z ustalonymi efektami indywidualnymi.

$\mathrm{Z}$ większości równań wynika, że nierówności dochodowe w sposób istotny statystycznie wyjaśniają zmienność wskaźnika skolaryzacji. Wyjątki stanowią równania FE (4), FE (5) oraz (RE 7), w których współczynniki regresji stojące przy zmiennej nierówności dochodowych okazują się nieistotne statystycznie. Cechą wspólną tych równań jest uwzględnienie wśród zmiennych objaśniających zmiennej PKB per capita, która nie zmienia ujemnej wartości współczynnika przy zmiennej Giniego, lecz wyjaśnia zmiany wskaźnika skolaryzacji lepiej niż nierówności dochodowe. Można zatem sądzić, że poziom rozwoju gospodarczego „przejmuje” efekty nierówności dochodowych dla kapitału ludzkiego. Jednocześnie z badań przekrojowych (oszacowanie 1 i 2) wynika, że poziom nierówności dochodowych wpływa negatywnie na akumulację kapitału ludzkiego nawet wtedy, gdy kontrolowana jest zmienna PKB per capita. Wyniki te ilustrują, że skutki nierówności dla kapitału ludzkiego ujawniają się w długim okresie. Na podstawie użytej metody badawczej nie można było wiarygodnie uchwycić konsekwencji krótkookresowych zmian nierówności dochodowych dla skolaryzacji przy założeniu stałego PKB per capita.

Tabela 2. Oszacowania regresji o postaci (1) i (2), gdzie zmienną zależną są wyniki testów edukacyjnych (Edu_achiev)

\begin{tabular}{|c|c|c|c|c|}
\hline \multirow{2}{*}{ Wyszczególnienie } & \multicolumn{4}{|c|}{ Równanie } \\
\hline & OLS (09) & OLS (10) & RE (13a) & $\mathrm{RE}(14 a)$ \\
\hline Gini $_{t-1}$ & $\begin{array}{c}-0,295^{* * * * *} \\
(0,050)\end{array}$ & $\begin{array}{c}-0,225^{* * * * *} \\
(0,062)\end{array}$ & $\begin{array}{c}-0,248^{* * * *} \\
(0,068)\end{array}$ & $\begin{array}{c}-0,190^{* *} \\
(0,082)\end{array}$ \\
\hline$y r_{-} s c h_{t-1}$ & $\begin{array}{c}0,966^{* * * * *} \\
(0,208)\end{array}$ & $\begin{array}{c}0,722^{* * * * *} \\
(0,213)\end{array}$ & $\begin{array}{c}1,240^{* * * * *} \\
(0,270)\end{array}$ & $\begin{array}{c}1,047^{* * * * *} \\
(0,284)\end{array}$ \\
\hline Urban_pop $p_{t-1}$ & $\begin{array}{c}0,079 \text { **** } \\
(0,023)\end{array}$ & $\begin{array}{c}0,033 \\
(0,023)\end{array}$ & $\begin{array}{c}0,088^{* * * *} \\
(0,029)\end{array}$ & $\begin{array}{c}0,044 \\
(0,028)\end{array}$ \\
\hline $\log \mathrm{PKB}_{t-1}$ & - & $\begin{array}{c}1,562^{* * * *} \\
(0,507)\end{array}$ & - & $\begin{array}{l}1,371^{* *} \\
(0,655)\end{array}$ \\
\hline Efekty czasowe & tak & tak & tak & tak \\
\hline$N$ & 336 & 324 & 336 & 324 \\
\hline$R^{2}$ & 0,6432 & 0,654 & 0,484 & 0,501 \\
\hline Skorygowany $R^{2}$ & 0,6311 & 0,6401 & 0,467 & 0,481 \\
\hline
\end{tabular}

Objaśnienia: odporne błędy standardowe w nawiasach; poziom istotności obliczono na podstawie wartości $p:{ }^{* * * *} 0,001,{ }^{* * *} 0,01,{ }^{* *} 0,05, * 0,1$.

Źródło: opracowanie własne. 
Tabela 3. Wyniki testów diagnostycznych

\begin{tabular}{|c|c|c|c|c|}
\hline Model & $\begin{array}{c}\text { Test Breuscha- } \\
\text {-Pagana na hetero- } \\
\text { skedastyczność } \\
\text { reszt }^{\mathrm{a}}\end{array}$ & $\begin{array}{l}\text { Test F dla efektów } \\
\text { indywidualnych }\end{array}$ & Test Hausmanna ${ }^{c}$ & $\begin{array}{c}\text { Test efektów } \\
\text { losowych Breuscha- } \\
\text {-Pagana }\end{array}$ \\
\hline OLS (1) & $\begin{array}{c}\mathrm{BP}=18,548, \mathrm{df}=11, \\
\quad \text {-value }=0,070\end{array}$ & - & - & - \\
\hline OLS (2) & $\begin{array}{c}\mathrm{BP}=25,964, \mathrm{df}=12, \\
p \text {-value }=0,011\end{array}$ & - & - & - \\
\hline FE (3) & $\begin{array}{c}\mathrm{BP}=11,893, \mathrm{df}=3 \\
p \text {-value }=0,008\end{array}$ & $\begin{array}{c}\mathrm{F}=8,3616, \\
\mathrm{df} 1=108, \mathrm{df} 2=532, \\
p \text {-value }=0,000\end{array}$ & $\begin{array}{c}\text { chisq }=27,254, \mathrm{df}=3 \\
p \text {-value }=0,000\end{array}$ & - \\
\hline FE (3a) & $\begin{array}{c}\mathrm{BP}=18,548, \mathrm{df}=11, \\
p \text {-value }=0,070\end{array}$ & $\begin{array}{c}\mathrm{F}=10,123, \\
\mathrm{df} 1=116, \mathrm{df} 2=524, \\
p \text {-value }=0,000\end{array}$ & $\begin{array}{c}\text { chisq }=92,216, \mathrm{df}=11 \\
p \text {-value }=0,000\end{array}$ & - \\
\hline FE (4) & $\begin{array}{c}\mathrm{BP}=19,269, \mathrm{df}=4 \\
\quad p \text {-value }=0,001\end{array}$ & $\begin{array}{c}\mathrm{F}=8,2302, \\
\mathrm{df} 1=108, \mathrm{df} 2=486, \\
p \text {-value }=0,000\end{array}$ & $\begin{array}{c}\text { chisq }=56,891, \mathrm{df}=4 \\
p \text {-value }=0,000\end{array}$ & - \\
\hline FE (5) & $\begin{array}{c}\mathrm{BP}=25,964, \mathrm{df}=12 \\
\quad p \text {-value }=0,011\end{array}$ & $\begin{array}{c}\mathrm{F}=9,0175 \\
\mathrm{df} 1=116, \mathrm{df} 2=478 \\
p \text {-value }=0,000\end{array}$ & $\begin{array}{c}\text { chisq }=37,861, \\
\mathrm{df}=12, \\
p \text {-value }=0,000\end{array}$ & - \\
\hline RE (6) & $\begin{array}{c}\mathrm{BP}=11,893, \mathrm{df}=3 \\
\quad p-\text { value }=0,008\end{array}$ & - & $\begin{array}{c}\text { chisq }=27,254, \\
\mathrm{df}=3, \\
\text {-value }=0,000\end{array}$ & - \\
\hline RE (6a) & $\begin{array}{c}\mathrm{BP}=18,548, \mathrm{df}=11, \\
\quad \text {-value }=0,070\end{array}$ & - & $\begin{array}{c}\text { chisq }=92,216, \mathrm{df}=11 \\
\text { p-value }=0,000\end{array}$ & - \\
\hline RE (7) & $\begin{array}{c}\mathrm{BP}=19,269, \mathrm{df}=4 \\
p \text {-value }=0,001\end{array}$ & - & $\begin{array}{c}\text { chisq }=56,891, \mathrm{df}=4 \\
p \text {-value }=0,000\end{array}$ & - \\
\hline RE (8) & $\begin{array}{c}\mathrm{BP}=25,964, \mathrm{df}=12, \\
p \text {-value }=0,011\end{array}$ & - & $\begin{array}{c}\text { chisq }=37,861, \mathrm{df}=12 \\
p \text {-value }=0,000\end{array}$ & - \\
\hline OLS (9) & $\begin{array}{c}\mathrm{BP}=33,658, \mathrm{df}=11 \\
\quad p \text {-value }=0,000\end{array}$ & - & - & - \\
\hline OLS (10) & $\begin{array}{c}\mathrm{BP}=37,081, \mathrm{df}=12, \\
\quad p \text {-value }=0,000\end{array}$ & - & - & - \\
\hline RE (13a) & $\begin{array}{c}\mathrm{BP}=33,658, \mathrm{df}=11 \\
\quad p \text {-value }=0,000\end{array}$ & - & - & $\begin{array}{c}\text { chisq }=15605, \mathrm{df}=1 \\
p-\text { value }=0,000\end{array}$ \\
\hline RE (14a) & $\begin{array}{c}\mathrm{BP}=37,081, \mathrm{df}=12, \\
p \text {-value }=0,000\end{array}$ & - & - & $\begin{array}{c}\text { chisq }=17526, \mathrm{df}=1, \\
p-\text { value }=0,000\end{array}$ \\
\hline
\end{tabular}

${ }^{a}$ test Breuscha-Pagana z hipotezą zerową o braku heteroskedastyczności reszt, ${ }^{\mathrm{b}}$ test $\mathrm{F}$ dla efektów indywidualnych (modele FE porównywano z modelami OLS o odpowiadającej im specyfikacji): hipoteza zerowa - wszystkie wyrazy wolne mają tę samą wartość, ${ }^{\mathrm{c}}$ test Hausmanna (modele FE porównywano z modelami RE o odpowiadającej im specyfikacji, tj. model FE (3) z RE (6), FE (3a) z RE (7), FE (4) z RE (8), FE (5) z RE (9)): hipoteza zerowa - oba estymatory są zgodne i nieobciążone, ale MNK dla modelu RE jest bardziej efektywna. Hipoteza alternatywna - estymator RE jest obciążony, ${ }^{d}$ test Breuscha-Pagana efektów losowych (porównano model RE (13a) z OLS (9) oraz RE (14a) z OLS (10)): hipoteza zerowa - wariancja składnika losowego indywidualnego jest równa zeru. Źródło: opracowanie własne. 
W tabeli 2 zawarto wyniki estymacji parametrów równań o postaciach (1) i (2), gdzie zmienną zależną były wyniki testów kompetencji i umiejętności (Edu_achiev). Podobnie jak w oszacowaniach zawartych w tabeli 1, także wszystkie równania w tabeli 2 ilustrują negatywną zależność między nierównościami dochodowymi a inwestycjami w kapitał ludzki.

Wyniki tych oszacowań, a więc wyjaśniających zmienność inwestycji w kapitał ludzki w ujęciu jakościowym, rodzą jednak większe trudności interpretacyjne w porównaniu z szacowaniami dla wskaźnika Enr_sec. Wartości współczynników determinacji $\left(R^{2}\right.$ oraz skorygowany $R^{2}$ ) estymowanych dla równań, gdzie zmienną zależną jest Edu_achiev, ilustrują gorsze dopasowanie do danych empirycznych niż oszacowania zawarte w tabeli 1. W szczególności oszacowania uwzględniające efekty indywidualne wykazywały tak małe dopasowanie, że niemożliwe było wnioskowanie na ich podstawie. Oznacza to, że jakość inwestycji w kapitał ludzki zależy od czynników innych niż te ujęte w równaniach (1) i (2), a w szczególności od instytucjonalnych rozwiązań w systemie edukacji. Wnioski takie wynikają z badań mikroekonomicznych ilustrujących, że sposób organizacji procesu edukacyjnego ma większe znaczenie dla osiąganych wyników niż nawet nakłady na edukację [Hanushek i Woessmann 2010, s. 24-35]. Można także przypuszczać, że niskie dopasowanie modelu wynika również z wysokich błędów pomiarowych jakości kapitału ludzkiego.

\section{Podsumowanie}

W artykule przeanalizowano znaczenie nierówności dochodowych dla inwestycji w kapitał ludzki w grupie 105 krajów. O ile z przeglądu literatury teoretycznej wynikają przekonujące argumenty za negatywnym wpływem rosnących nierówności dochodowych na inwestycje w kapitał ludzki, o tyle z podjętych badań empirycznych trudno wyciągnąć tak jednoznaczne wnioski.

W szczególności w badanej grupie krajów na różnym poziomie rozwoju ekonomicznego wykazano negatywne znaczenie rosnących nierówności dochodowych dla inwestycji w kapitał ludzki mierzonych współczynnikiem skolaryzacji na poziomie średnim. W związku z tym wykazano, że większym zróżnicowaniom dochodowym towarzyszą niższe inwestycje w kapitał ludzki w wymiarze ilościowym.

Jednocześnie na podstawie zebranych danych statystycznych, a także zastosowanej metody badawczej nie udało się uzyskać na tyle miarodajnych wyników, aby sformułować podobne wnioski dotyczące związków występujących między nierównościami dochodów oraz inwestycjami w kapitał ludzki w wymiarze jakościowym. W szczególności z niskich wartości współczynników determinacji 
$\left(R^{2}\right.$ i skor. $\left.R^{2}\right)$ wynika, że zmiany inwestycji w kapitał ludzki w ujęciu jakościowym są w niewielkim stopniu wyjaśniane przez zmienne niezależne. Słabe dopasowanie modelu do danych empirycznych wynikać może z zastosowanej postaci funkcyjnej. Można sądzić również, że otrzymane wyniki są artefaktem błędów pomiaru i odmiennych sposobów diagnozy kompetencji i umiejętności wykonywanych w różnych okresach w zróżnicowanej grupie państw świata, a także, że jakość kapitału ludzkiego zależy od innych zmiennych, w szczególności od instytucjonalnych rozwiązań w systemie edukacji. Wyniki takie sugerują, że w przyszłych badaniach warto poszukiwać zależności między nierównościami dochodowymi a kapitałem ludzkim w mniejszych i bardziej homogenicznych grupach państw.

\section{Literatura}

Anderson L.R., Mellor J.M., Milyo J. [2008], Inequality and Public Good Provision: An Experimental Analysis, ,The Journal of Socio-Economics”, vol. 3, nr 37, https://doi.org/ 10.1016/j.socec.2006.12.073.

Angrist N., Patrinos H.A., Schlotter M. [2013], An Expansion of a Global Data Set on Educational Quality a Focus on Achievement in Developing Countries, ,World Bank Policy Research Working Paper", nr 6536.

Atkinson A.B. [1997], Bringing Income Distribution in from the Cold, „Economic Journal”, vol. 107, https://doi.org/10.1111/1468-0297.00159.

Azariadis C. [1996], The Economics of Poverty Traps Part One: Complete Markets, „Journal of Economic Growth”, vol. 1, nr 4, https://doi.org/10.1007/bf00150197.

Azariadis C., Drazen A. [1990], Threshold Externalities in Economic Development, „The Quarterly Journal of Economics”, vol. 105, nr 2, https://doi.org/10.2307/2937797.

Baltagi B.H. [2013], Econometric Analysis of Panel Data, 5th ed., John Wiley \& Sons, Chichester, Sussex.

Barro R.J., Lee J.W. [2013], A New Data Set of Educational Attainment in the World, 1950-2010, , Journal of Development Economics”, vol. 104, https://doi.org/10.1016/ j.jdeveco.2012.10.001.

Bartak J. [2015], Wpływ nierówności dochodowych na akumulację kapitału ludzkiego ujęcie teoretyczne, „Nierówności Społeczne a Wzrost Gospodarczy”, nr 41.

Battisti M., Fioroni T., Lavezzi A.M. [2014], World Interest Rates, Inequality and Growth: an Empirical Analysis of the Galor-Zeira Model, Discussion Paper, nr 184, Dipartimento di Economia e Management (DEM), University of Pisa, Pisa, Italy, https://ideas. repec.org/p/pie/dsedps/2014-184.html (data dostępu: 1.06.2016).

Becker G.S. [1962], Investment in Human Capital: A Theoretical Analysis, „Journal of Political Economy", vol. 70, nr 5, part 2, https://doi.org/10.1086/258724.

Becker G.S. [1964], Human Capital: A Theoretical and Empirical Analysis, with Special Reference to Education, University of Chicago Press, Chicago.

Becker G.S., Murphy K.M., Tamura R. [1990], Human Capital, Fertility, and Economic Growth, „Journal of Political Economy”, vol. 98, nr 5, https://doi.org/10.1086/261723. 
Bell L.A., Freeman R.B. [2001], The Incentive for Working Hard: Explaining Hours Worked Differences in the US and Germany, „Labour Economics” vol. 8, nr 2, https:// doi.org/10.1016/s0927-5371(01)00030-6.

Benabou R. [1996a], Equity and Efficiency in Human Capital Investment: The Local Connection, ,Review of Economic Studies”, vol. 63, nr 2.

Benabou R. [1996b], Heterogeneity, Stratification, and Growth: Macroeconomic Implication of Community Structure and School Finance, „American Economic Review”, vol. 86, nr 3, https://doi.org/10.2307/2297851.

Bertrand M., Morse A. [2015], Trickle-Down Consumption, „CEPR Discussion Paper”, nr DP10468.

Croix D. de la, Doepke M. [2003], Inequality and Growth: Why Different Fertility Matters, „The American Economic Review”, vol. 93, nr 4, https://doi.org/10.1257/ 000282803769206214.

Dahan M., Tsiddon D. [1998], Demographic Transition, Income Distribution, and Economic Growth, ,,Journal of Economic Growth”, vol. 3.

Denison E.F. [1962], The Sources of Economic Growth in the United States and the Alternatives before Us, Supplementary Paper, nr 13, Committee for Economic Development, New York.

Domański R.S. [1993], Kapitał ludzki i wzrost gospodarczy, PWN, Warszawa.

Ehrhart C. [2009], The Effects of Inequality on Growth: A Survey of the Theoretical and Empirical Literature, ,ECINEQ Working Paper”, nr 107.

Fernández R., Rogerson R. [1998], Public Education and Income Distribution: A Dynamic Qualitative Evaluation of Education-finance Reform, „The American Economic Review", vol. 88, $\mathrm{nr} 4$.

Fernández R., Rogerson R. [2003], Equity and Resources: An Analysis of Education Finance Systems, „The Journal of Political Economy”, vol. 111, nr 4, https://doi.org/ $10.1086 / 375381$.

Foellmi R., Zweimüller J. [2003], Inequality and Economic Growth: European versus US Experiences, „CESifo Working Paper”, nr 158.

Forbes K.J. [2000], A Reassessment of the Relationship between Inequality and Growth, „American Economic Review”, vol. 90, nr 4, https://doi.org/10.1257/aer.90.4.869.

Frank R.H., Levine A.S., Dijk O. [2014], Expenditure Cascades, „Review of Behavioral Economics", vol. 1, nr 1-2, https://doi.org/10.1561/105.00000003.

Galor O. [2011], Inequality, Human Capital Formation and the Process of Development, „National Bureau of Economic Research Working Paper”, nr w17058.

Galor O. [2012], Inequality, Human Capital Formation and the Process of Development, Institute for Study of Labor, Discussion Paper Series, IZA DP nr 6328, January.

Galor O., Tsiddon D. [1997], The Distribution of Human Capital and Economic Growth, „Journal of Economic Growth”, vol. 2, nr 1.

Galor O., Weil D.N. [2000], Population, Technology, and Growth: From Malthusian Stagnation to the Demographic Transition and Beyond, „American Economic Review”, vol. 90, $\mathrm{nr}$ 4, https://doi.org/10.1257/aer.90.4.806.

Galor O., Zeira J. [1993], Income Distribution and Macroeconomics, „, Review of Economic Studies", vol. 60, nr 1, https://doi.org/10.2307/2297811.

Glomm G., Ravikumar B. [1992], Public versus Private Investment in Human Capital: Endogenous Growth and Income Inequality, ,Journal of Political Economy”, vol. 100, nr 4, https://doi.org/10.1086/261841. 
Hanushek E.A., Wöessmann L. [2010], The Economics of International Differences in Educational Achievement, ,National Bureau of Economic Research Working Paper”, nr w15949.

Jabłoński Ł. [2011], Kapitał ludzki w wybranych modelach wzrostu gospodarczego, „Gospodarka Narodowa”, nr 1-2.

Klenow P., Rodríguez-Clare A. [1997], The Neoclassical Revival in Growth Economics: Has It Gone Too Far?, eds B.S. Bernanke, J. Rotemberg, NBER Macroeconomics Annual, vol. 12, MIT Press, Cambridge.

Kuznets S. [1955], Economic Growth and Income Inequality, „The American Economic Review", vol. 45, nr 1.

Leigh A., Jencks C., Smeeding T.M. [2009], Health and Economic Inequality [w:] The Oxford Handbook of Economic Inequality, eds S. Wiemer, T.M. Smeeding, B. Nolan, Oxford.

Lucas R.E. Jr [1988], On the Mechanics of Economic Development, ,Journal of Monetary Economics", vol. 22, nr 1, https://doi.org/10.1016/0304-3932(88)90168-7.

Lynch J., Smith G.D., Harper S., Hillemeier M., Ross N., Kaplan G.A., Wolfson M. [2004], Is Income Inequality a Determinant of Population Health? Part 1. A Systematic Review, ,Milbank Quarterly”, vol. 82, nr 1, https://doi.org/10.1111/j.0887378x.2004.00302.x.

Mankiw N.G., Romer D., Weil D.N. [1992], A Contribution to the Empirics of Economic Growth, „Quarterly Journal of Economics”, vol. 107, nr 2, https://doi.org/ $10.2307 / 2118477$.

Masson P.R. [2001], Migration, Human Capital, and Poverty in a Dual-economy Model of a Developing Country, IMF Working Paper, nr WP/01/128.

Mincer J. [1958], Investment in Human Capital and Personal Income Distribution, ,Journal of Political Economy", vol. 66, nr 4, https://doi.org/10.1086/258055.

Mincer J. [1962], On-the-Job Training: Costs, Returns, and Some Implications, ,Journal of Political Economy", vol. 70, nr 5, part 2, https://doi.org/10.1086/258725.

Papageorgiou C., Razak N.A.A. [2009], Inequality, Human Capital and Development: Making the Theory Face the Facts, „MPRA Paper”, nr 18973.

Perotti R. [1996], Growth, Income Distribution, and Democracy: What the Data Say, „Journal of Economic Growth”, vol. 1, nr 2, https://doi.org/10.1007/bf00138861.

Putterman L., Roemer J.E., Silvestre J. [1998], Does Egalitarianism Have a Future?, „Journal of Political Literature”, vol. 36, June.

Rajan R.G., Zingales L. [2006], The Persistence of Underdevelopment: Institutions, Human Capital, or Constituencies?, „CEPR Discussion Paper”, nr 5867.

Romer P.M. [1986], Increasing Returns and Long-run Growth, „Journal of Political Economy, vol. 94, nr 5, https://doi.org/10.1086/261420.

Romer P.M. [1990], Endogenous Technological Change, „Journal of Political Economy”, vol. 98, nr 5, https://doi.org/10.1086/261725.

Schultz T.W. [1961], Investment in Human Capital, „American Economic Review”, vol. 51, nr 1.

Solt F. [2014], The Standardized World Income Inequality Database, version 5.0, October, http://myweb.uiowa.edu/fsolt/papers/Solt2014 (data dostępu: 8.02.2016).

Stiglitz J.E. [2010], Freefall. Jazda bez trzymanki, PTE, Warszawa.

Stockhammer E. [2015], Rising Inequality as a Cause of the Present Crises, „Cambridge Journal of Economics", vol. 39, nr 3, https://doi.org/10.1093/cje/bet052. 
Tamura R. [2001], Teachers, Growth, and Convergence, „The Journal of Political Economy”, vol. 109, nr 5, https://doi.org/10.1086/322830.

Tamura R. [2004], Human Capital and Economic Development, Federal Reserve Bank of Atlanta, Working Papers Series, WP 2004-34, December.

Welch F. [1999], In Defense of Inequality, „American Economic Review”, vol. 89, nr 2, https://doi.org/10.1257/aer.89.2.1.

\section{The Importance of Income Inequality for Human Capital Investment in the Period 1970-2012}

(Abstract)

The paper presents an empirical analysis of the importance of income inequality for human capital investment in various countries of the World between 1970 and 2012. The analysis was conducted with the estimation of regression parameters, with quantitative and qualitative measures of human capital investment as independent variables. With the analysis based on panel data, it was possible to control the calculations for individual countries, time and random effects. That is the contribution to the debate over the relations between income inequality and quantitative investment in human capital. Our calculations show a negative relationship between income inequality and quantitative measures of human capital investment. This negative relationship is resistant to the model's specifications. However, the calculation results do not allow us to draw conclusions about the relationships between income inequality and a qualitative measure of human capital investment.

Keywords: human capital, income inequality, endogenous growth theory, fixed effects. 